\title{
Effect of genotype on haematology and serum biochemistry of Nigerian indigenous roosters (cockerels)
}

\author{
Ilo, S. U. ${ }^{1}$ and Egu, U. N. ${ }^{2 *}$ \\ 1Department of Animal Science, University of Nigeria Nssuka, Enugu State, Nigeria. \\ 2Department of Animal Science and Fisheries Abia State University PMB 7010 Umuahia, Nigeria. \\ Corresponding author. Email: ucheegu1@gmail.com
}

Copyright (C) 2018 Ilo and Egu. This article remains permanently open access under the terms of the Creative Commons Attribution License 4.0, which permits unrestricted use, distribution, and reproduction in any medium, provided the original work is properly cited.

Received 25th August, 2018; Accepted 4th October, 2018

\begin{abstract}
An experiment was conducted to determine the haematology and serum biochemistry of three genotypes of Nigerian indigenous roosters. A total of twenty-seven roosters aged 8 months were used. They were divided into 3 treatment groups as $T_{1}, T_{2}$ and $T_{3}$, representing frizzled, naked neck and normal feathered roosters respectively. Each of the treatment group consisted of Nine (9) roosters, replicated 3 times with 3 roosters per replicate in a completely randomized design (CRD). They were fed grower mash for 35 days after which blood samples were collected for haematological and serum biochemical evaluation. The parameters measured included haemoglobin $(\mathrm{Hb})$, red blood cell (RBC), white blood cell (WBC), packed cell volume (PCV), mean corpuscular volume (MCV), mean corpuscular haemoglobin $(\mathrm{MCH})$, mean corpuscular heamoglobin concentration $(\mathrm{MCHC})$, total protein, albumin, urea, globulin, glucose, creatinine and cholesterol. The results of the study revealed that all the parameters measured showed no significant differences $(P>0.05)$ among the treatment groups although variations were observed among the different genotypes. More so, almost all the parameters measured are within the normal ranges for chicken.
\end{abstract}

Keywords: Blood chemistry, genotype, haematology, indigenous chicken.

\section{INTRODUCTION}

Indigenous chickens are widely distributed in the rural areas of tropical and sub-tropical countries where they are kept by the majority of the rural poor. The indigenous chicken constitutes $80 \%$ of the 120 million poultry types raised in the rural areas in Nigeria (RIM, 1992). They are self-reliant and hardy birds with the capacity to withstand harsh weather condition and adapt to adverse environment. They are known to possess qualities such as the ability to hatch on their own, brood and scavenge for major parts of their food and possess appreciated immunity from endemic diseases. Their products are preferred by the majority of Nigerians because of the pigmentation, taste, leanness and suitability for special dishes (Horst, 1989). In Nigeria, indigenous chickens were characterized along genetic lines of feather and plumage colour (such as normal or frizzled feathered), body structure (such as naked neck, dwarf type) and colour variants (such as black, white, brown, mottled etc.). The frequency distribution of the normal feathered chicken was about $91.8 \%$ while that of frizzled and naked neck were 5.2 and $3.0 \%$ respectively in Bayelsa state of Nigeria (Ajayi et al., 2009). The use of blood examination as a way of assessing the health status of animals has been documented (Muhammad et al., 2000; Esonu et al., 2001; Churias, 2002; Iheukwumere et al., 2004; Iheukwumere et al., 2006; Iheukwumere et al., 2008; Oguike and Ude, 2008). This is because it plays a vital role in physiological, nutritional and pathological status of organisms (Muhammad et al., 2000; Iheukwumere and Okoli, 2002; Egbe-Nwiiyi et al., 2000; Taiwo and Ogunsami, 2003). Serum biochemical analysis is used to determine the level of heart, liver and kidney functions as well as to evaluate 
protein quality and amino acid requirements in animals (Etim and Oguike, 2011). This study was therefore designed to determine the effect of genotype on haematological and serum biochemical parameters and invariably health status of Nigerian indigenous cockerels.

\section{MATERIALS AND METHODS}

\section{Location of the study}

The experiment was carried out at the Poultry Unit of the Students' Research and Teaching Farm of Federal College of Agriculture, Ishiagu, Ivo Local Government Area of Ebonyi State. The project site is located within latitude $5^{0} 56^{\prime}$ North and Longitude $7^{0} 3^{\prime}$ East, having a mean annual rainfall of $100-1,600 \mathrm{~mm}$ and a temperature of 27$33^{\circ} \mathrm{C}$ with an average relative humidity of $88 \%$ (Metrological unit of FCAI).

\section{Experimental birds and management}

A total of 27 birds were used for the study. They comprised three different genetic groups 9 frizzle, 9 naked neck and 9 normal feathered whose previous management background is unknown. They were purchased from local markets in South eastern Nigeria. The roosters were acclimatized for a period of two weeks. During this acclimatization, the cocks was given all the necessary medications which include; vaccination against Newcastle disease, and deworming. The birds were raised on a deep litter pen. They were fed using commercial feed (Grower Mash) diet (Table 1). Feed and water were given ad-libitum to the birds, while other management practices were also carried out.

\section{Experimental design}

The cockerels were randomly assigned to 3 treatment groups of 9 birds replicated 3 times with 3 birds per replicate in a Completely Randomized Design (CRD).

\section{Blood collection and analysis}

Blood samples of about $5 \mathrm{mls}$ were collected using a sterile syringe and needle via wing vein puncture. About $2.5 \mathrm{mls}$ of blood used for haematological studies was stored in a bottle containing anticoagulant; ethylene diamine tetra acetic acid (EDTA) to prevent clotting and subsequently analyzed. While the other $2.5 \mathrm{mls}$ of blood meant for serum biochemical studies was collected into another sterile bottle and allowed to coagulate. The samples were centrifuged to harvest the sera. Haematological parameters measured include haemoglobin $(\mathrm{Hb})$, packed cell volume (PCV), red blood cell count (RBC), white blood cell (WBC) count. The blood constants: mean corpuscular haemoglobin concentration (MCHC), mean corpuscular volume (MCV) and mean corpuscular haemoglobin ( $\mathrm{MCH})$ were computed using appropriate formulae as described by Jain (1986). Haematological parameters were evaluated according to the procedure described by Davis and Lewis (1991). The serum biochemical assay was carried out using standard chemical procedures: total serum protein by Goldbery refractometer method as described by Kohn and Allen (1995), albumin and globulin by Bromocresol green (BCG) method as described by Randox (2006), creatinine was determined according to the procedure described by Boisness and Taussky (1995), while urea, glucose and cholesterol were determined by methods described by Baker and Silverton (1986). The analyses were carried out in the laboratory.

\section{Statistical analysis}

Data collected on haematology and serum biochemistry were subjected to one-way analysis of variance (ANOVA). The separation of significant means was carried out using Fishers Protected Least Significance Difference (LSD) as outlined by Steel and Torrie (2006). Statistical model that was used is:

$Y_{i j}=\mu+T_{i}+e_{i j}$

Where; $\mu=$ overall mean common to all observation, $T_{i}=$ Effect of strain on the observation and $e_{i j}=$ Error term.

\section{RESULTS AND DISCUSSION}

The haematological parameters of three Nigerian indigenous cockerels are shown in Table 2. There were no significant differences $(P>0.05)$ among the treatment groups in all the parameters measured: PCV, HB, RBC, $\mathrm{MCHC}, \mathrm{MCH}$. MCV and WBC values.

The range of PCV values is 37.67 to $39.00 \%$, with the frizzle feathered having the highest numerical count of PCV $39.00 \%$, followed by naked neck $(38.00 \%)$ and then normal feathered had the lowest value of $37.67 \%$. The PCV values obtained in this study were within the range of 25 to $45 \%$ reported for birds by Banerjee (2007) and Islam et al. (2004).

Haemoglobin values ranged from 12.77 to $13 \mathrm{~g} / \mathrm{dl}$. The frizzle feathered cockerels had the highest numerical value, followed by naked neck and then normal feathered cockerels: $13.17,12.80$ and $12.77 \%$, respectively. These values were within the normal HB range of 7 to $13 \mathrm{~g} / \mathrm{dl}$ reported by Banerjee (2007) for chickens. However, the HB values obtained in this study were higher than the range of $9.36 \pm 0.01$ to $9.39 \pm 0.00 \mathrm{~g} / \mathrm{dl}$ reported by Iheukwumere et al. (2006) for Nigerian indigenous 
Table 1. Ingredients composition of the commercial concentrate (Top Grower's Mash) fed to the birds.

\begin{tabular}{lc}
\hline Ingredients Composition & Percent (\%) \\
\hline Crude Proteins & 16.00 \\
Fats and Oil & 5.00 \\
Crude Fibre & 7.00 \\
Calcium & 1.00 \\
Available Phosphorus & 0.45 \\
Lysine & 0.75 \\
Methionine & 0.36 \\
Salt (g) & 0.30 \\
Kcal/K Metabolisable Energy (ME) & 2450 \\
\hline
\end{tabular}

Table 2. Haematological characteristics of three Nigerian indigenous roosters.

\begin{tabular}{lcccc}
\hline Parameters & $\mathbf{T}_{\mathbf{1}} \mathbf{F}$ & $\mathbf{T}_{\mathbf{2}} \mathbf{N K}$ & $\mathbf{T}_{\mathbf{3}} \mathbf{N}$ & $\mathbf{S E M}$ \\
\hline PCV \% & 39.00 & 38.00 & 37.67 & 11.16 \\
$\mathrm{HB}(\mathrm{g} / \mathrm{dl})$ & 13.17 & 12.80 & 12.77 & 1.39 \\
$\mathrm{RBC}\left(\mathrm{X} 10^{12} / \mathrm{l}\right)$ & 4.33 & 3.76 & 3.62 & 0.58 \\
MCHC (\%) & 33.75 & 33.68 & 33.88 & 0.11 \\
MCH (pg) & 30.52 & 34.11 & 35.31 & 26.22 \\
MCV (fl) & 90.42 & 101.26 & 104.46 & 134.07 \\
WBC $\left(\times 10^{12} /\right)$ & 6.40 & 6.63 & 7.07 & 7.07 \\
\hline
\end{tabular}

PCV-packed cell volume, HB-Haemoglobin, RBC-Red Blood Cell, MCHC-Mean Corpuscular Haemoglobin Concentration, MCH-Mean Corpuscular Haemoglobin, MCV-Mean Corpuscular Volume, WBC-White Blood Cell, F- Frizzled Feathered, NK-Naked Neck, N-Normal Feathered.

chickens, but lower than the range of $11.00 \pm 2.15$ to $14.85 \pm 1.42 \mathrm{~g} / \mathrm{dl}$ reported by Iheukwumere et al. (2008) for Nigerian local cocks. Since haemoglobin is responsible for cellular respiration which is important in metabolic reactions (Mc. Donald et al., 2002), a decrease in haemoglobin is an important determinant of anaemia which may probably lead to reduction in the oxygen carrying capacity of blood. Haemoglobin concentration in the blood has been associated with availability of nutrient to the animal (Esonu et al., 2001; Iheukwumere and Herbert, 2002; Egu and Ukpabi, 2015).

The RBC values ranged from 3.62 to $4.33\left(\times 10^{12} / \mathrm{l}\right)$. The Frizzle feathered cockerels had the highest numerical value of $4.33\left(x 10^{12} / l\right)$ in RBC, followed by the Naked neck cockerels which had $3.76\left(\times 10^{12} / \mathrm{l}\right)$ and then the Normal feathered cockerels which had the lowest RBC value of $3.62\left(\times 10^{12} / l\right)$. The RBC values obtained in this study were within the normal range of 2 to $4\left(x 10^{6} / \mathrm{mm}^{3}\right)$ reported by Jain (1993) for chickens except that of frizzle feathered cockerels which was slightly higher than the range. However, the RBC values obtained were lower than the range of 8 to $11\left(x 10^{6} / \mathrm{mm}^{3}\right)$ reported by Simaraks et al. (2004) in Thai indigenous chickens.

$\mathrm{MCHC}$ values ranged from 33.68 to $33.88 \%$. The normal feathered cockerels had the highest numerical value of $33.88 \%$ in MCHC, followed by Frizzle feathered and naked neck cockerels which had 33.75 and $33.68 \%$ respectively. The $\mathrm{MCHC}$ values obtained in this study were lower than the value of $35.70 \%$ reported by lheukwumere et al. (2002) in broiler chickens, but higher than the value of $30.56 \%$ reported by Ameh (2004) in Nigerian local cocks and the range of 33.20 to $33.40 \mathrm{~g} / \mathrm{dl}$ reported by Egu (2017) in Harco cocks. However, the MCHC values obtained in this study were within the normal range of 26.0 to $35.0 \mathrm{~g} / \mathrm{dl}$ reported by Banerjee (2007) for chickens and Islam et al. (2004) for local chickens in Bangladesh.

The $\mathrm{MCH}$ result ranged from 30.52 to $35.31 \mathrm{pg}$ with the normal feathered having the highest count followed by naked neck while the frizzle feathered had the least $\mathrm{MCH}$ value as 35.31 and $30.52 \mathrm{pg}$ respectively. Frizzled and naked necks are within the normal range of 30.7 to 34.10 for $\mathrm{MCH}$ reported by Ibrahim (2012) in chickens.

The MCV value ranged from 90.42 to $104.00 \mathrm{fl}$. The normal feathered had the highest value of $104.46 \mathrm{fl}$, followed by naked neck with value of $101.26 \mathrm{fl}$ and frizzle feathered with least value $90.42 \mathrm{fl}$. The MCV range is in the normal range for chicken MCV count reported by naked neck (Ibrahim, 2012). Mean corpuscular volume (MCV) of blood is an indication of the average volume of blood cell (Lazzaro, 2003).

The WBC values ranged from 6.40 to $7.07\left(\times 10^{12 / 1}\right)$. Normal feathered had the highest count followed by naked 
Table 3. Serum biochemical characteristics of three Nigerian indigenous roosters.

\begin{tabular}{lcccc}
\hline Parameters & $\mathbf{T}_{\mathbf{1}} \mathbf{F}$ & $\mathbf{T}_{\mathbf{2}} \mathbf{N K}$ & $\mathbf{T}_{\mathbf{3}} \mathbf{N}$ & $\mathbf{S E M}$ \\
\hline Protein $(\mathrm{g} / \mathrm{l})$ & 40.73 & 42.13 & 39.47 & 2.17 \\
Albumin $(\mathrm{g} / \mathrm{l})$ & 24.50 & 25.83 & 24.56 & 1.78 \\
Globulin $(\mathrm{g} / \mathrm{l})$ & 16.23 & 16.30 & 14.93 & 1.22 \\
Urea $(\mathrm{mg} / \mathrm{dl})$ & 35.61 & 36.17 & 35.50 & 6.52 \\
Creatinine $(\mathrm{mg} / \mathrm{dl})$ & 2.65 & 2.12 & 1.09 & 0.49 \\
Cholesterol $(\mathrm{mg} / \mathrm{dl})$ & 93.46 & 95.38 & 86.92 & 3.85 \\
\hline
\end{tabular}

F- Frizzled Feathered, NK- Naked Neck, N- Normal Feathered.

and frizzle feathered with the values of $7.07,6.53$ and 6.40 $\left(x 10^{12 / 1}\right)$ respectively. Banerjee, (2007) reported the normal range for WBC of chicken as $9.31\left(\times 10^{12 / 1}\right)$. The range from the result was far below this range thus, disagrees with it. Abnormal production of white blood cell in the blood of animals is usually associated with immune response by animals due to the presence of antigen (foreign body) in the body. The values of white blood cell also depict absence of infections since elevation of the cell suggests infection by micro-organisms especially bacteria (Aka et al., 2008; Sowande et al., 2008).

The serum biochemical parameters of three Nigerian indigenous cockerels are shown in Table 3 . There were no significant differences $(P>0.05)$ among the treatment groups in all the parameters measured: total protein, albumin, globulin, urea, creatinine and cholesterol values. Naked neck cockerels recorded the highest numerical value of $42.13 \mathrm{~g} / \mathrm{l}$ in total protein followed by frizzle and normal feathered cockerels which had $40.73 \mathrm{~g} / \mathrm{l}$ and 39.47 $\mathrm{g} / \mathrm{l}$ respectively. The serum total protein values obtained in this study were higher than the range of $7.6 \pm 0.27$ to $8.2 \pm 0.30 \mathrm{mg} / \mathrm{dl}$ reported by lheukwumere et al. (2006) for Nigerian chickens. This variation in values of serum total protein may not be unconnected to the differences in breed and nutritional status of the birds (Esonu et al., 2001).

Naked neck cockerels recorded the highest numerical value of $25.83 \mathrm{~g} / \mathrm{l}$ in serum albumin followed by the Normal feathered and the Frizzle cockerels which had $24.56 \mathrm{~g} / \mathrm{l}$ and $24.50 \mathrm{~g} / \mathrm{l}$ respectively. The serum albumin values obtained in this study were higher than the range of $3.1 \pm 0.27$ to $3.5 \pm 0.22 \mathrm{mg} / \mathrm{dl}$ reported by lheukwumere et al. (2006) for Nigerian chickens. Low albumin suggests poor clotting ability of blood and hence poor prevention of hemorrhage (Robert et al., 2000; Egu, 2017).

Naked neck cockerels recorded the highest numerical value of $16.30 \mathrm{~g} / \mathrm{l}$ in serum globulin followed by the Frizzle and Normal feathered cockerels which had $16.23 \mathrm{~g} / \mathrm{l}$ and $14.93 \mathrm{~g} / \mathrm{l}$ respectively. The serum globulin values obtained in this study were higher than the range of 2.1 to $3.7 \mathrm{~g} / \mathrm{dl}$ reported for birds by Banerjee (2007). Babatunde and Oluyemi (2006) opined that the higher the value of globulin, the better the ability to fight against disease. This implies that naked neck cockerels which recorded the highest value of $16.30 \mathrm{~g} / \mathrm{l}$ in globulin could have the best ability to resist disease.
Naked neck cockerels recorded the highest numerical value of $36.17 \mathrm{mg} / \mathrm{dl}$ in serum urea followed by the Frizzle and Normal feathered cockerels which had 35.61 and $35.50 \mathrm{mg} / \mathrm{dl}$ respectively. The urea values obtained in this study were within the range of $30.46 \pm 2.51$ to $54.08 \pm 0.11$ $\mathrm{mg} / \mathrm{dl}$ reported by lheukwumere et al. (2006) in Nigerian chickens. However, the urea values obtained in this study were higher than the range of 10.20 to $29.74 \mathrm{mg} / \mathrm{dl}$ reported by Egu (2017) in Harco cocks. This disparity in urea values may be attributed to differences in breed and nutritional status of the birds. It has been observed that serum urea content depends on both the quantity and quality of protein supplied in the diet (Iheukwumere and Herbert, 2002).

Frizzle cockerels recorded the highest numerical value of $2.65 \mathrm{mg} / \mathrm{dl}$ in serum creatinine followed by the naked neck and normal feathered cockerels which had 2.12 and $1.09 \mathrm{mg} / \mathrm{dl}$ respectively. The serum creatinine values obtained in this study were within the range of 1 to $2 \mathrm{mg} / \mathrm{dl}$ reported for birds by Reece and Swenson (2004) and Banerjee (2007) except Frizzle cockerels whose creatinine value was slightly higher than the range. However, the creatinine values obtained in this study were lower than the range of 18.00 to $18.50 \mathrm{mg} / 100 \mathrm{ml}$ reported by Iheukwumere et al. (2002) in broiler chickens. Creatinine measurement is used exclusively in the assessment of kidney function. The rate of production of creatinine is constant and elevations of plasma creatinine are indicative of under excretion suggesting kidney impairment. Stockham and Scott (2007) reported also that creatinine along with blood urea nitrogen concentration is an excellent indicator of protein metabolism and kidney function.

Naked neck cockerels recorded the highest numerical value of $95.38 \mathrm{mg} / \mathrm{dl}$ in serum cholesterol, followed by the Frizzle and Normal feathered cockerels which had 93.46 and $86.92 \mathrm{mg} / \mathrm{dl}$ respectively. The cholesterol values obtained in this study were within the normal range of 52 to $148 \mathrm{mg} / \mathrm{dl}$ reported by Banerjee (2007) for birds. This implies that the cockerels may not face the risk of myocardial infarction usually associated with high blood cholesterol content and emaciation due to low serum cholesterol (Frandson, 2002). A decrease in plasma cholesterol concentration has been reported to result in a reduction in the plasma concentrations of insulin-like 
growth factor and progesterone and consequently delayed or inhibited ovulation (Maciel et al., 2010).

The assessment of the nutritional and health status in livestock can be made by determining certain blood metabolite concentrations (Ndlova et al., 2007). The authors further reported that certain factors like physiological status of an animal, breed, nutrition, season and age may affect the concentration of blood biochemical parameters. Ihrig et al. (2001) and Mohri et al. (2007) reported that blood biochemical parameters have been shown to be subject to change with age in many animal species.

\section{Conclusion}

The results of this study indicate that haematology and serum biochemistry of the Nigerian indigenous roosters may not be influenced by genotype. Though variations were observed in all the parameters measured, there were no significant differences among the three genotypes. Also, most of the values obtained are within the normal ranges for chickens.

\section{REFERENCES}

Ajayi, F. O., Agaviezzor, B. O., \& Torukuru, S. (2009). Fertility and hatchability of indigenous chicken as influenced by major genes in the rainforest zone of Nigeria. Proceedings of the $13^{\text {th }}$ Annual Animal Science Association of Nigeria, September $15^{\text {th }}$ $-19^{\text {th }}, 2008$, Ahmadu Bello University, Zaria, Pp. 81-83.

Aka, L. O., Eze, L., Ofor, G. C., \& Igbokwe, C. O. (2008). Time dependent postpartum Haematological, Biochemical and Rectal Temperature Changes in West African Dwarf Ewes. Nigerian Society for Animal Production Proceeding $23^{\text {rd }}$ Annual Conference. Pp. 111-115.

Ameh, M. (2004). Effect of Pergonal $^{\circledR}$ on Semen Quality, Haematological values and carcass characteristics of the Nigerian local cocks. M.Sc. Thesis Department of Animal Science and Fisheries, Abia State University, Umuahia, Nigeria.

Banerjee, G. C. (2007). A Textbook of Animal Husbandry (8 ${ }^{\text {th }}$ edition). Oxford and IBH Publishing co PVT Ltd New Delhi India.

Boisness, R. W., \& Taussky, H. H. J. (1985). Determination of creatinine in plasma and urine. J. Biol. Chem., 58, 581-589.

Churias, N. U. (2002). Haematological changes observed in a clinical case of infectious bronchitis complicated with $E$. coli. Proceeding XXI World Poultry Congress August 20-24, 2000, Montreal Canada (CD ROM).

Davis, J. V. \& Lewis, S. M. (1991). Practical Haematology. 8th edition, Long Group Ltd. Pp. 21-68

Egbe-Nwiiyi, T. N., Wafarand, E., \& Nwosu, S.C. (2000). Haematological and biochemical values in apparently healthy camels (Camelus dromidarius) in semi-arid zone of Borno State, Nigeria. Tropical Vet., 18:128-132.

Egu, U. N. (2017). Haematologial and Serum Biochemical Parameters of Mature Harco cocks Treated with Human Menopausal Gonadotrophin (Diclair ${ }^{\circledR}$ ) for Spermatogenesis. Inter. J. Environ., Agric. and Biotech., 2(1), 429-436.
Egu, U. N., \& Ukpabi, U. H. (2015). Effect of Gonadotrophin (Pergonal $^{\circledR}$ ) on haematology, immune/leucocyte status and serum metabolites of mature Yankasa rams treated for sperm production, Inter. J. Vet. Sci., 4(4): 216 - 220.

Esonu, B. O., Emelalom, O. O., Udedibie, A. B. I., Herbert, U., Ekpor, C. F., Okoli, I. C., \& Iheukwumere, F. C. (2001). Performance and Blood Chemistry of Weaner pigs Fed Raw Mucuna bean (velvet bean) meal. Trop. Anim. Prod. Invest., 4, 49-54.

Etim, N. N., \& Oguike, M.A. (2011). Haematology and Serum Biochemistry of Rabbits Does Fed Aspilia africana. Nigerian Journal of Agriculture, Food and Environment, 7(4), 121-127.

Frandson, R. D. (2002). Anatomy and Physiology of farm animals $3^{\text {rd }}$ ed. Published by Bialiere Tindal, London, Pp. 32-54.

Horst, P. (1989). Native fowl as a reservoir for genomes and major genes with direct and indirect effects on the adaptability and their potential for tropically oriented breeding plans; a review. Anim. Res. Dev., 33, 63-79.

Ibrahim, A. (2012). Haematological and Some Biochemical Values of Indigenous Chickens in Al-Ahsa, Suadi Arabia during Simmer Season. Asian Jornal of Poultry Science, 6,138-145.

Iheukwumere, F. C., \& Okoli, I. C. (2002). Preliminary studies on raw Napoleona imperialis as feed ingredient. Performance and blood chemistry of weaner rabbits. Trop. Anim. Prod. Invest. 113: $1-9$.

Iheukwumere, F. C., Abu A. H., \& Ndubuisi, E. C. (2008). Effect of $\mathrm{FSH}$ and $\mathrm{LH}\left(\right.$ Pergonal $\left.^{\circledR}\right)$ Treatment on Haematology, Immune Status and serum Metabolites of West African Dwarf Goats. Journal of Animal and Veterinary Advances 7(1), 46-50.

Iheukwumere, F. C., Abu, A. H., \& Ameh, M. (2006). Effect of human menopausal gonadotrophin on haematological and serum biochemical parameters of Nigerian indigenous chickens. International Journal of Poultry Sciences, 5(7), 632634.

Iheukwumere, F. C., Herbert, U., \& Ewulu, C. (2002). Effect of quantitative feed restriction on broiler chickens. J. Sustainable Trop. Agric. Res., 4, 56-60.

Iheukwumere, F. C., Herbert, U., \& lloeje, M. U. (2004). Haematological and serum Biochemical values of West African Dwarf Does Following FSH + LH (Pergonal $\left.{ }^{\circledR}\right)$ Treatment Int. J. Agric. Rural Dev., 5, 54-60.

Iheukwumere, F.C. and Herbert, U. (2002). Physiological responses of broiler chickens to quantitative water restriction. Haematology and Serum Biochemistry. International Journal of Poultry Science, 2(2), 117-119.

Ihrig, M., Tassinary, L. G., Bernacky, B., Keeling, M. E. (2001). Haematologic and serum biochemical reference intervals for the Chimpanzee (Pantroglodytes) categorized by age and sex. Comp. Med., 51(1), 30-37.

Islam, M. S., Lucky, N. S., Islam, M. R., Ahadi, A., Das, B. R., Rahman, M. M., \& Siddini, M. S. I. (2004). Haematology Parameters of Fayoumi Assil and Local Chickens Reared in Bangladesh. Int. J. Poultry Sci., 3:144-147.

Jain, N. C. (1986). Veterinary Haematology.4th edition. Baillere, Tindall. Pp. 297.

Jain, N. C. (1993). Essential of Veterinary Haematology, Lea and Ferbiger, Philadelphia.

Kohn, R. A., \& Allen, M. S. (1995). Enrichment of proteolytic activity relative to nitrogen in preparations from the rumen for in vitro studies. Anim. Feed Science and Technology. 52(1/2), $1-14$.

Lazzaro, J. (2003). Normal blood chemistry for goats, Saanendoah dairy goats. Available at http/www.Saanedoah.com/bloodvalues.html//measures. 
Maciel, M., Marais, S. M., Bevilaqua, C. W., Silva, R. A., Baros, R. S., Sousa, R. N., Sousa, L. C., Brito, E. S., \& Sousa-Neto, M. A. (2010). Chemical Composition of Eucalyptus spp. essential oils and their insecticidal effects on Lutzomyia longipalpis. Vet. Parasitol., 167(1), 1-7.

Mc. Donald, P., Edward, R. A., Green Halgh, J. F. D., \& Morgan, C. C. (2002). Animal Nutrition. $5^{\text {th }}$ Ed. Longman, Pp 30-65.

Mohri, M., Sharifi, K., \& Eidi, S. (2007). Hematology and serum biochemistry of Holstein dairy calves: age related changes and comparison with blood composition in adults. Research in Veterinary Science, 83(1), 30-39.

Muhammad, N. O., Adeyina, A. O. \& Peters, O. M. (2000). Nutritional evaluation of fungi treated cocoa bean shell. Nigerian J. Pure and Appl. Sci., 5, 1059-1064.

Ndlova, T, Chimonyo,M., Okoh, A. J., Muchenje, V., Dzama, K., \& Racts, J. G. (2007). Assessing the nutritional status of beef cattle; current practices and future prospects. Afr. J. Biotech., 6(24), 2717-2734.

Oguike M. A., \& Ude, N. E. (2008). Influence of the Ethno veterinary plant, Spondias mombi $L$. on partial daily milk yield (PDM), haematology and serum biochemistry of lactating West African Dwarf (WAD) ewes. J. Anim. Vet. Adv., 7, 584-588.

Randox (2006). www.Raidox.Com/Randox.Laboratory Ltd. Users' Manual.

RIM (Resource Inventory and Management Ltd) (1992). Nigeria National Livestock Survey. Federal Department of Livestock and Pest Control Services, Abuja, Nigeria, p. 287.
Simaraks, S., Chinrasri, O., \& Aengwanich, S. (2004). Haematological, Electrolyte and serum Biochemical values of the Thai Indigenous chickens (Gallus domesticus) in North Eastern Thailand-song Klanakarin J. Sci. Tec., 26, 425.

Sowande, O. S., Aina, A. B. J., Oguntona, E. B., Fanimo, A. O., Unaka, V. U., Itassan, T. A., \& Oseni, M. O. (2008). Performance, Biochemical Constituents and Mineral Balance of West African Sheep Fed Preserved Elephant Grass, Layer's Droppings and Cassava Peel Diet during Dry Season. Nig. J. Anim. Prod., (35), 90-102.

Steel, R. D. G., \& Torrie, J. H. (2006). Principles and Procedures of Statistics. $3^{\text {rd }}$. Edn. McGraw-Hill Book Co. Inc., New York.

Stockham, S. L., \& Scott M. A. (2002). Fundamentals of Veterinary Clinical Pathology. lowa State University Press, Ames. I. A. USA.

Taiwo, V. O., \& Ogunsami, A. O (2003). Haematology, plasma, whole blood and erythrocyte biochemical values of clinically healthy captive reared gray duiker (Sylvica pragrimmia) and West African Dwarf sheep and goats in Ibadan, Nigeria. Israel Vet. Med. Assoc., 1, 58. 